\title{
Design and Implementation of Travel Agent in the Face of the COVID-19 pandemic
}

\author{
Jauhari, A F Doni, Fifin Ayu Mufarroha *, Y D P Negara \\ Department of Mechanical Engineering, University of Trunojoyo Madura, Indonesia
}

\begin{abstract}
The tourism agent information system is an information system that brings together people who need tourism agents with tourism agent providers. This information system contains offers of tourism packages in several well-known tours that are often visited, this system is also available with request packages which will be directed to the admin to confirm with the desired request package. This system does not only contain offers about tour packages but also provides information and education about these tours, making it easier for users to choose the desired tour packages because they have received education or an overview of the tour. The development stages implemented include surveys, needs analysis, dedication, and implementation. Surveys and needs analysis serve as stages used in finding target users and their needs. User Interface Design is used to make user interaction as simple and efficient as possible, in terms of achieving user goals or what is often referred to as user-centered design. Conversion of the user interface design is done by choosing the right programming language on the web and generating an information system.
\end{abstract}

Keywords: Intelligent Plant; ADDI Model; Mobile Application; Learning Media

\section{Introduction}

Tourism is all activities in society related to tourists. From the statement that the presence of tourists who come makes community, private and government activities in a tourist destination increase. Tourism is one of the fastest growing industries in this century[1][4]. The development of tourism in the world can not be separated from globalization that is happening [5][6]. Tourism has become a potential contributor to the economy through the support and economic development in the tourism industry experienced by many countries[7]. Tourism has an important role in the development of Indonesia, especially as a foreign exchange earner in addition to the oil and gas sector. Indonesia is a country where almost all of its regions have tourist attractions, namely through its natural beauty and historical heritage. The territory of Indonesia that crosses the equator makes Indonesia have a climate that gives rise to a variety of flora and fauna that fascinates tourists to visit Indonesia. Indonesia's geographical condition in the form of tropical rain forests, mountains, beaches, and also the ocean and cultural diversity which is a very potential basic capital to become a world-famous Tourist Destination Area (DTW).

Against the backdrop of natural beauty and cultural diversity, Indonesia is a country that is famous for its tourist attractions, be it natural attractions or cultural attractions. In addition to maintaining the survival of tourism actors, income from tourist objects can also increase income for local governments in particular and the central government in general. Indonesia must be able to develop the tourism industry throughout the world. Currently, the world is being shaken by the case of the spread of the COVID-19 virus pandemic that originated in China, which is increasingly spreading and expanding rapidly and has become the biggest global polemic for now [8]-[13]. Even this virus outbreak has been designated as a global pandemic by the World Health Organization (WHO). This is what is now the talk and public discussion that is happening all over the world. After the statement stipulated by the WHO, of course, this becomes a problem that must be a serious concern by governments and people around the world [10], [14]-[17]. The world is becoming aware of this virus outbreak. Not only alert to the spread of the disease, but also alert to the possible impact on the world economy. The tourism sector is one of the most affected by the COVID-19 virus outbreak [8]. Tourism, which initially grew very rapidly, now seems to be weakening and experiencing a very drastic decline. The decline that has occurred in the tourism sector for now will not be able to be overcome until the case of the COVID-19 virus outbreak finds a bright spot for its resolution. Actually, you can still carry out tourism activities in the midst of this pandemic with good health protocols. With the help of the agent tourism you can prepare for your holiday properly and according to health protocols. However, people still do not dare to do this because of

\footnotetext{
* Corresponding author : fifin.mufarroha@trunojoyo.ac.id
} 
the lack of information. This can make the tourism bureau company go bankrupt or in the worst case it can go out of business.

Therefore, the use of web-based tourism agent information systems must now be developed. This is so that the tourism industry can continue to thrive in the midst of the COVID-19 pandemic. With this system, potential tourists can be sure to travel with good health protocols. In this system, prospective tourists can view travel packages easily by simply opening a browser. If the package provided does not match what potential tourists want. They can make requests as they wish. In addition, in this system, prospective tourists can make payments if they are interested in using the services of a tourism agent.

\section{Methodology}

In the development of the tourism agent information system, several stages of research were applied as shown in Figure 1. These stages began with exploring the need, namely conducting a field survey. Followed by analyzing system requirements and used as an initial understanding of development. Based on the results of the analysis, a system modeling is made to make it easier for developers to implement at a later stage.

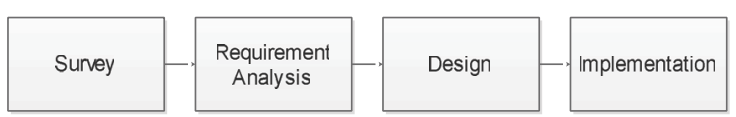

Fig. 1. Block diagram.

\section{Results and Discussion}

\subsection{System requirements survey}

This stage conducted a survey via the internet, and it was found that the average tourism agent needed a simple, innovative and attractive Webpage. For this reason, it was decided to create a Web page with an attractive UI and an orderly database so that both the service tenant and the service provider can benefit.

\subsection{Requirements analysis}

The information system created has the main function as a liaison between customers and stakeholder [18][19]. Apart from the customer side, this system also helps in dealing with Transaction Reports for the Tourism agency company. At the same time, we provide convenience in the transaction process between customers and their tourism agents. The planned system, will require some hardware \& software. As for the hardware, we need 4 PCs as Admin \& also as a Virtual Server to store the data. This system also requires some software such as Text Editor, Database Planner, Web Hosting, DBMS (Database Management System). For operator level needs, it does not require too many personnel, it takes 7 people to be admin \& maintenance team. The admin is in charge of managing this Information System and also being a liaison between the system and the Company, for example in terms of providing transaction reports for tourism agents and synchronizing customer data. The Maintenance Team serves as a system supervisor, system maintainer and performs system development based on requests from the tourism agency company.

\subsection{Design}

The design stage is chosen by designing the user interface [20]. User interface design is the design for software, computers, equipment, machines, and websites that focuses on the user experience and interaction [21].

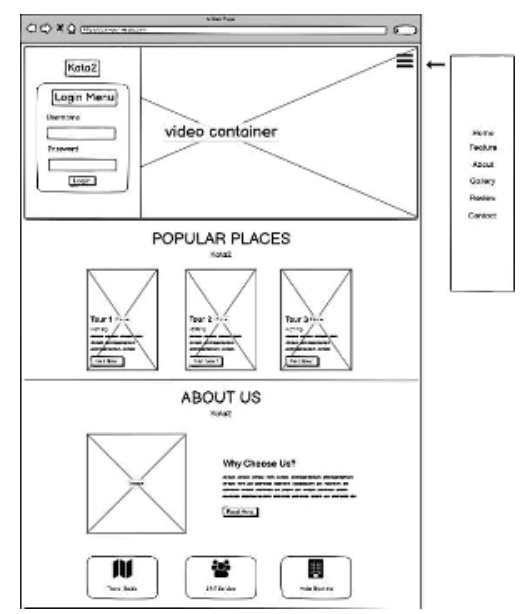

(a)

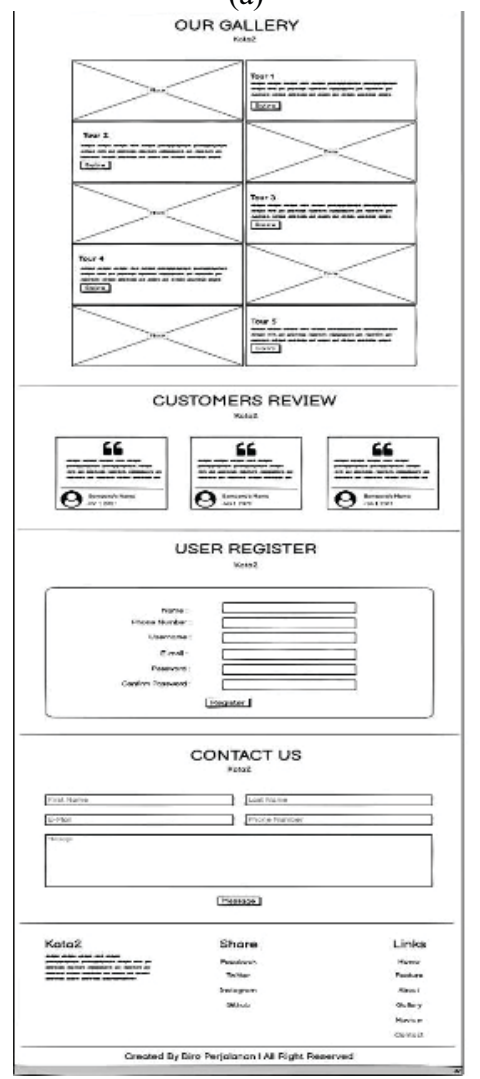

(b)

Fig. 2. User Interface Design 1: Tourism agent information system 

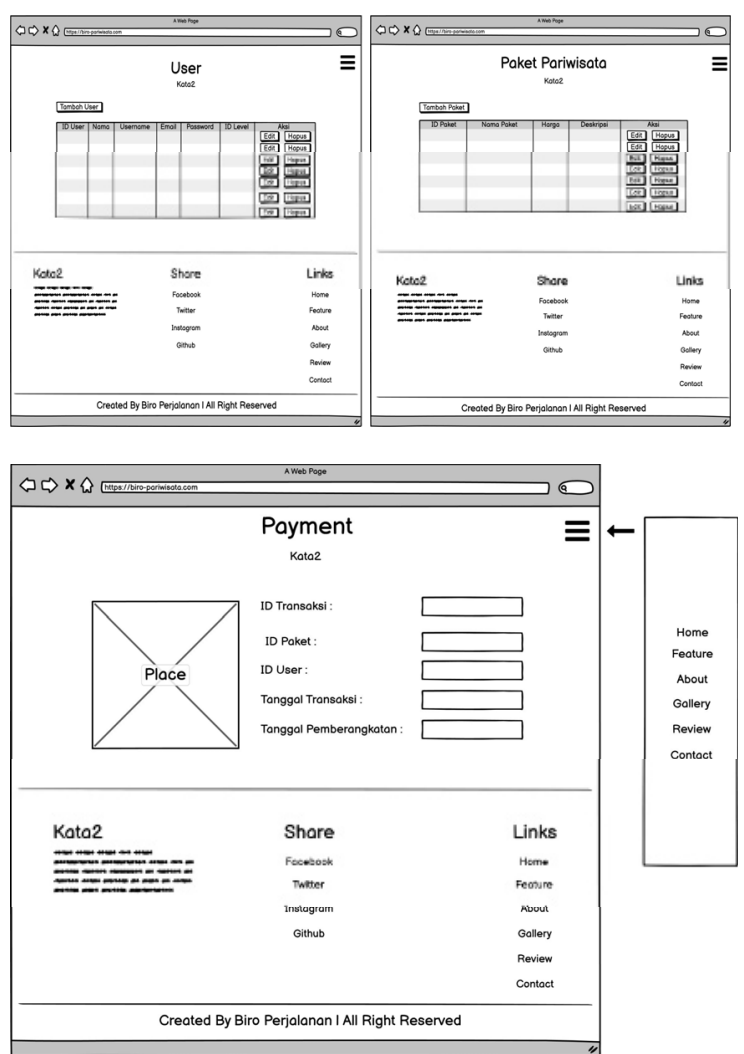

Fig. 3. User Interface Design 2: Tourism agent information system

\subsection{Implementation}

The creation of a web-based tourism agent system is based on a pre-designed user interface. Some of the information system pages that have been created can be seen in the image below.

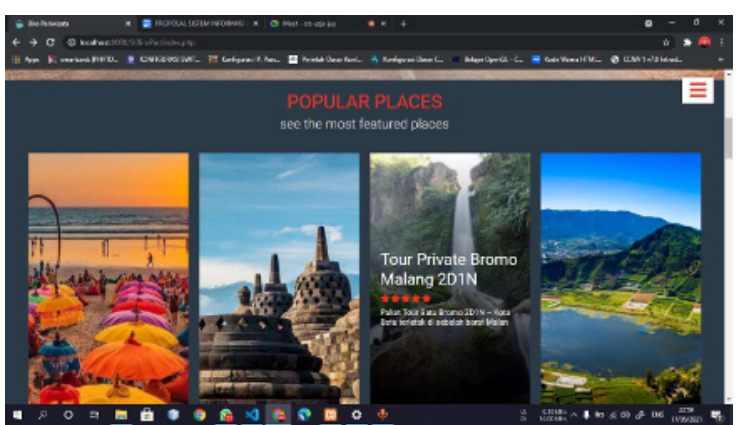

Fig. 4. Home page

The homepage will contain information about the tourism bureau package that has been determined by the admin. This is the main page or the first page that appears on this page, the user is not required to log in because this only contains information about tourism agents and the packages offered and here will also be shown about the packages that are popularly used, the comment column, and the display of reviews or comments from customer.

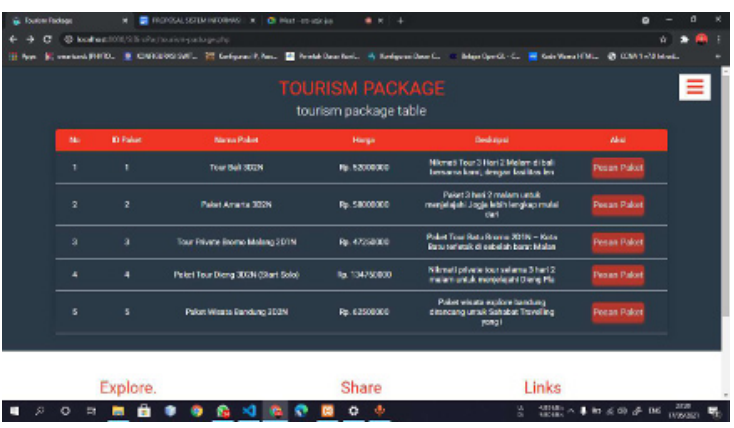

Fig. 5. Tourism Package

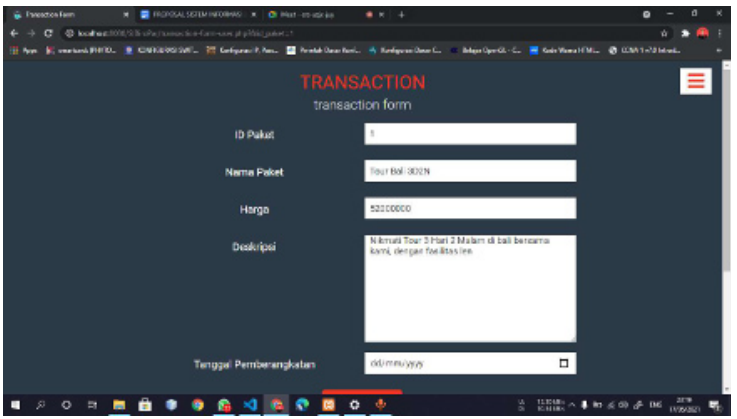

Fig. 6. Booking a tourism package

This page is used to manage tour packages that will be provided later by tourism agents (Figure 5). This page can be accessed by Administrators and Customers. Users can choose a travel package that is considered attractive by booking a package (Figure 6).

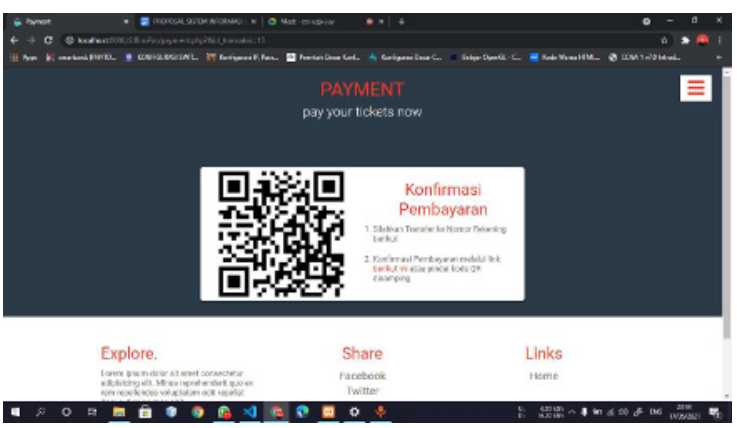

Fig. 7. Payment page

From the results of the order, the user can take the next step by making a payment. The tourism agent system has been equipped with payment through the system and will later ask for confirmation from the user (Figure 7).

\section{Conclusion}

From the data that has been obtained during the observation. It can be concluded that the services offered to consumers are to fulfill the wishes of tourists who want to use services, especially in the field of tourism. With this tourism agent information system, it can make it easier for managers to manage their tourism agent business. Not only that, it is also easier for customers to make reservations for vacations, especially tourists who are out of town or who don't have time to go to the place or office of the business agent owner. Not only makes it easier for customers or the owner of this agent, it also has a positive impact on the destination tour because it 
is also a means of promotion and tourism education. Because the tourist attractions offered by the tourism bureau can be reached widely by utilizing this system because it can be accessed anywhere as long as it is still affordable by the internet.

\section{References}

[1] M. A. Camilleri, "The Tourism Industry: An Overview BT - Travel Marketing, Tourism Economics and the Airline Product: An Introduction to Theory and Practice," M. A. Camilleri, Ed. Cham: Springer International Publishing, 2018, pp. 3-27.

[2] C. Ceccarini and C. Prandi, "Tourism for all: a mobile application to assist visually impaired users in enjoying tourist services," in 2019 16th IEEE Annual Consumer Communications \& Networking Conference (CCNC), 2019, pp. 16, doi: 10.1109/CCNC.2019.8651848.

[3] M. Afzaal, M. Usman, and A. Fong, "Tourism Mobile App With Aspect-Based Sentiment Classification Framework for Tourist Reviews," IEEE Trans. Consum. Electron., vol. 65, no. 2, pp. 233-242, 2019, doi: 10.1109/TCE.2019.2908944.

[4] S. K. Viswanath, C. Yuen, X. Ku, and X. Liu, "Smart Tourist - Passive Mobility Tracking Through Mobile Application BT - Internet of Things. IoT Infrastructures," 2015, pp. 183191.

[5] F. Higgins-Desbiolles, S. Carnicelli, C. Krolikowski, G. Wijesinghe, and K. Boluk, "Degrowing tourism: rethinking tourism," $J$. Sustain. Tour., vol. 27, no. 12, pp. 1926-1944, Dec. 2019, doi: 10.1080/09669582.2019.1601732.

[6] F. Higgins-Desbiolles, "Sustainable tourism: Sustaining tourism or something more?," Tour. Manag. Perspect., vol. 25, pp. 157-160, 2018, doi: https://doi.org/10.1016/j.tmp.2017.11.017.

[7] R. Scheyvens and R. Biddulph, "Inclusive tourism development," Tour. Geogr., vol. 20, no. 4, pp. 589-609, Aug. 2018, doi: 10.1080/14616688.2017.1381985.

[8] T. D. Pham, L. Dwyer, J.-J. Su, and T. Ngo, "COVID-19 impacts of inbound tourism on Australian economy," Ann. Tour. Res., vol. 88, p. 103179, 2021, doi: https://doi.org/10.1016/j.annals.2021.103179.

[9] E. Razumovskaia, L. Yuzvovich, E. Kniazeva, M. Klimenko, and V. Shelyakin, "The Effectiveness of Russian Government Policy to Support SMEs in the COVID-19 Pandemic," Journal of Open Innovation: Technology, Market, and Complexity, vol. 6, no. 4. 2020, doi: 10.3390/joitmc6040160.

[10] S. E. Obi, T. Yunusa, A. N. Ezeogueri-Oyewole, S. S. Sekpe, E. Egwemi, and A. S. Isiaka, "The Socio-Economic Impact of Covid-19 on The Economic Activities of Selected States in Nigeria ," Indones. J. Soc. Environ. Issues, vol. 1, no. 2 SE-, pp. 39-47, Aug. 2020, doi: 10.47540/ijsei.v1i2.10.

[11] T. Hale et al., "A global panel database of pandemic policies (Oxford COVID-19 Government Response Tracker)," Nat. Hum. Behav., vol. 5, no. 4, pp. 529-538, 2021, doi: 10.1038/s41562-021-01079-8.

[12] A. Altiparmakis, A. Bojar, S. Brouard, M. Foucault, H. Kriesi, and R. Nadeau, "Pandemic politics: policy evaluations of government responses to COVID-19," West Eur. Polit., vol. 44, no. 5-6, pp. 1159-1179, Sep. 2021, doi: 10.1080/01402382.2021.1930754.

[13] F. C. Permana, Z. M. Wicaksono, C. Kurniawan, A. S. Abdullah, and B. N. Ruchjana, "Perception analysis of the Indonesian society on twitter social media on the increase in BPJS kesehatan contribution in the Covid 19 pandemic era," J. Phys. Conf. Ser., vol. 1722, p. 12022, 2021, doi: 10.1088/17426596/1722/1/012022.

[14] Y. Xiao, B. Becerik-Gerber, G. Lucas, and S. C. Roll, "Impacts of Working From Home During COVID-19 Pandemic on Physical and Mental Well-Being of Office Workstation Users," $J$. Occup. Environ. Med., vol. 63, no. 3, pp. 181190, Mar. 2021, doi: 10.1097/JOM.0000000000002097.

[15] T. M. Yildirim and H. Eslen-Ziya, "The differential impact of COVID-19 on the work conditions of women and men academics during the lockdown," Gender, Work Organ., vol. 28, no. S1, pp. 243-249, Jan. 2021, doi: https://doi.org/10.1111/gwao.12529.

[16] J. J. Ratcliff, K. I. Minster, and C. Monheim, "Engaging students in an online format during the COVID-19 pandemic: A jury voir dire activity.," Scholarsh. Teach. Learn. Psychol., 2021, doi: 10.1037/st10000246.

[17] J. Bodilsen et al., "Hospital admission and mortality rates for non-covid diseases in Denmark during covid-19 pandemic: nationwide population based cohort study," $B M J$, vol. 373, p. n1135, May 2021, doi: 10.1136/bmj.n1135.

[18] A. Jauhari and F. Ayu, "The Development of Information Systems for Measuring Student Performance at MTs Al-Azhar Paseseh Tanjung Bumi," vol. 04, no. 01, pp. 1-4, 2019.

[19] A. Jauhari, F. A. Mufarroha, M. Rofi', M. F. Nasrullah, Fitriyah, and K. Nisa, "The Development of Smart Travel Guide Application in Madura Tourism," vol. 473, no. Icss, pp. 771-776, 2020, doi: 10.2991/assehr.k.201014.167.

[20] B. Rusyn et al., "The Mobile Application Development Based on Online Music Library for Socializing in the World of Bard Songs and Scouts' Bonfires BT - Advances in Intelligent Systems and Computing IV," 2020, pp. 734756.

[21] A. A. Syahidi, A. A. Supianto, and H. Tolle, "Design and implementation of Bekantan Educational Game (BEG) as a Banjar language 
learning media," Int. J. Interact. Mob. Technol.,

vol. 13, no. 3, pp. 108-124, 2019, doi:

10.3991/ijim.v13i03.9257. 